\title{
Optimization design of thermal system for industrial waste heat power generation
}

\author{
Sun Fengchang ${ }^{1}$, Li Shiyue ${ }^{1}$, Bai Zhonghua ${ }^{1}$ Miao Changhai ${ }^{*}{ }^{*}$ Deng Xiaochuan ${ }^{1}$, Yu Dogyang ${ }^{1}$, Zhang Zhichao ${ }^{1}$ \\ ${ }^{1}$ Beijing Branch-State Grid Information And telecommunication Group, Beijing, China
}

\begin{abstract}
In order to improve the utilization rate of industrial waste heat and improve the fine design level of waste heat power station, this paper constructs the mathematical model of waste heat boiler and steam turbine, and puts forward the optimization design method of thermal system of waste heat power generation project. By using typical cases, it is proved that there is the optimal design pressure of HRSG, which makes the power generation of the system maximum, and provides a method to improve the power generation of HRSG.
\end{abstract}

\section{Introduction}

China is rich in industrial waste heat resources, which are widely used in various industrial production processes. According to statistics, waste heat resources account for about $17 \% \sim 67 \% \%^{[1]}$ of the total fuel consumption, of which the recovery rate is up to $60 \%{ }^{[2]}$. There is great potential for energy saving in the field of industrial waste heat. Waste heat power generation technology has been widely used in sintering machine, cement kiln, glass furnace and other fields, but there are still some problems, such as low utilization rate of flue gas waste heat, unreasonable design of thermal system and so on. In order to improve the fine design level of waste heat power generation, it is necessary to study the optimization design technology of waste heat power generation.

Many scholars have carried out extensive research in the field of waste heat power generation.Dong Shuai studied the utilization technology on waste heat boiler $^{[3]}$. Liu Yongming studied the design technology of waste heat boiler at cement kiln head ${ }^{[4]}$. Chen Xi Xi studied the selection and calculation of waste heat power generation equipment ${ }^{[5]}$. Kang Jianxi studied the design technology of waste heat boiler in ceramic industry [6]. However, the research on the optimal design of the thermal system of waste heat power generation is still blank.

This paper provides the design method of the thermal system of waste heat power generation from flue gas, constructs the mathematical model of the thermal system of waste heat power generation, and puts forward the optimization design method, which is verified by a case.

\section{Thermal system of waste heat power station}

The thermal system of industrial waste heat power station mainly includes waste heat boiler subsystem and steam turbine subsystem, as shown in Figure 1.

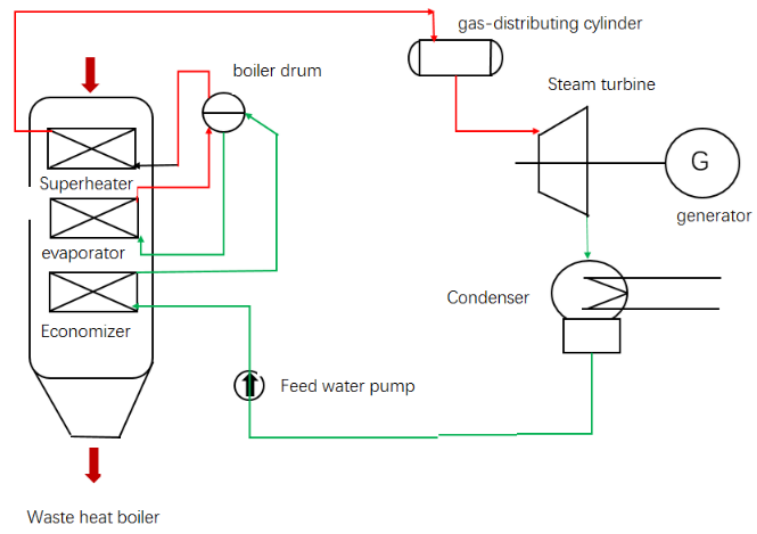

Fig 1 Thermal system diagram of typical waste heat power station

Waste heat boiler is a kind of equipment which converts the heat energy of industrial flue gas into steam heat energy. For the flue gas with large dust content, the vertical boiler is generally used. The flue gas side enters from the upper part of the boiler and flows out from the lower part. The feed water enters from the lower part of the boiler and flows out from the upper part. The counter current heat exchange is formed between the flue gas side and the water side, which effectively increases the heat exchange temperature difference and saves the heat exchange area. After pressurized by the feed water pump, the feed water first enters the economizer, which is preheated to become the saturated water under this pressure, and then enters the steam drum. The saturated water enters the evaporator through the downcomer, and forms a steam water mixture after being heated. It enters the steam drum along the riser, and the vaporization process is completed through continuous natural circulation. The saturated steam enters the superheater and

$\overline{{ }^{*} \text { Corresponding author: miaochanghai } @ 163 . c o m}$ 
continues to be heated into superheated steam, then enters the cylinder.

The superheated steam expands in the steam turbine to do work, drives the impeller to rotate, converts the heat energy of the steam into kinetic energy of the impeller, and then drives the generator to generate electric energy. The exhausted steam from the steam turbine enters the condenser and forms condensate after being cooled by circulating water. The condensate enters the waste heat boiler after deaeration to complete a complete thermal cycle.

\section{Thermal system design}

In the design of waste heat power generation, the parameters of flue gas are determined, and the design task is to determine the temperature, pressure and enthalpy of key points such as economizer inlet, evaporator inlet, superheater outlet and steam turbine exhaust according to the flue gas conditions, so as to achieve the maximum amount of waste heat power generation.

\subsection{Mathematical model}

In order to calculate the thermal system parameters of waste heat power generation, the following mathematical models are established.

$$
\begin{aligned}
& t_{\mathrm{zf}}=T-P\left(P_{0}\right) \\
& T_{\mathrm{jd}}=t_{z f}+\Delta t_{j d} \\
& Q_{1}=M C_{y} \times\left(T_{j y}-T_{j d}\right) \\
& Q_{1}=m \times\left(h_{1}-h_{3}\right) \\
& h_{1}=h-P T\left(P_{0}, t_{c s}\right) \\
& t_{\mathrm{cs}}=T_{\mathrm{jy}}-\Delta \mathrm{t}_{\mathrm{sdc}} \\
& h_{3}=h-P_{l}\left(P_{0}\right) \\
& Q_{2}=M C_{y} \times\left(T_{\mathrm{jd}}-T_{\mathrm{py}}\right) \\
& Q_{2}=m \times\left(h_{3}-h_{4}\right) \\
& h_{4}=h-P T\left(P_{0}, t_{\mathrm{gs}}\right) \\
& S_{1}=S-P T\left(P_{0}, t_{c s}\right) \\
& h_{6}=h-P S\left(P_{p q}, S_{1}\right) \\
& h_{5}=h_{1}-\eta_{s} \times\left(h_{1}-h_{6}\right) \\
& W_{f d}=m \times\left(h_{1}-h_{5}\right) \times \eta_{e}
\end{aligned}
$$

Where: $t_{\mathrm{zf}}, t_{\mathrm{cs}}, t_{\mathrm{gs}}$ are the evaporation temperature, outlet steam temperature and feed water temperature of HRSG, ${ }^{\circ} \mathrm{C} ; \Delta t_{\mathrm{sdc}}, \Delta t_{\mathrm{jd}}$ are the upper end temperature difference and nodal temperature difference of $\mathrm{HRSG},{ }^{\circ} \mathrm{C}$; $T_{j y}, T_{j d}, T_{p y}$ are the inlet temperature, nodal flue gas temperature and exhaust temperature of $\mathrm{HRSG},{ }^{\circ} \mathrm{C} ; Q_{1}$, $Q_{2}$ are the exchange temperature of superheated section and economizer section of HRSG Heat, $\mathrm{kW} ; h_{1}, h_{3}, h_{4}, h_{5}$, $h_{6}$ are steam enthalpy at Superheater outlet, enthalpy at evaporator inlet, enthalpy at economizer inlet, steam turbine exhaust and isentropic enthalpy at exhaust point,
$\mathrm{kJ} / \mathrm{kg} ; C_{\mathrm{y}}$ is specific heat at constant pressure of flue gas, $\mathrm{kJ} /\left(\mathrm{Nm}^{3}{ }^{\circ} \mathrm{C}\right) ; M$ is flue gas flow, $\mathrm{Nm}^{3} / \mathrm{S} ; m$ is feed water flow, $\mathrm{kg} / \mathrm{S} ; S_{1}$ is steam inlet entropy, $\mathrm{kJ} /\left(\mathrm{kg}^{\circ} \mathrm{C}\right) ; P_{0}, P_{\mathrm{pq}}$ are boiler pressure and steam turbine exhaust pressure, respectively Force, $\mathrm{MPa} ; \eta_{\mathrm{s}}$ and $\eta_{\mathrm{e}}$ are relative internal efficiency of steam turbine and generator efficiency respectively; $W_{\mathrm{fd}}$ is the output power of generator, $\mathrm{kW}$.

\subsection{Design method}

The design and calculation of thermal system of waste heat boiler are generally carried out according to the following process (see Fig. 2)

(1) The pressure $P_{0}$ of HRSG is determined and the corresponding saturation temperature $t_{\mathrm{zf}}$ is calculated;

(2) According to temperature $t_{\mathrm{zf}}$ and node temperature difference $\Delta t_{\mathrm{jd}}$, the flue gas temperature $T_{\mathrm{jd}}$ at the outlet of economizer is calculated;

(3) According to the inlet flue gas temperature $t_{\mathrm{jy}}, t_{\mathrm{jd}}$ and flue gas flow of waste heat boiler, the total heat release $Q_{1}$ of flue gas in evaporation section and superheating section is calculated;

(4) The outlet temperature $t_{\mathrm{cs}}$ of boiler superheater is calculated according to the inlet flue gas temperature $T_{\mathrm{jy}}$ and the upper end difference $\Delta t_{\mathrm{sdc}}$;

(5) According to $t_{\mathrm{zf}} 、 t_{\mathrm{cs}} 、 P_{0}, h_{3}$ and $h_{1}$ are calculated, and then combined with $Q_{1}$, the superheated steam flow $m$ is obtained from the heat balance;

(6) According to the feed water temperature $t_{\mathrm{gs}}$ and $P_{0}$, the enthalpy value $h_{4}$ is calculated;

(7) According to $h_{3}, h_{4}$ and superheated steam flow $m$, the heat exchange $Q_{2}$ of economizer is calculated.

(8) The exhaust gas temperature $T_{\mathrm{py}}$ is calculated according to $Q_{2}$ and $T_{\mathrm{jd}}$.

When designing the principle thermodynamic system, the pressure formed by the height of the HRSG is ignored, and it is considered that the outlet steam pressure and the inlet water pressure of the HRSG are the same.

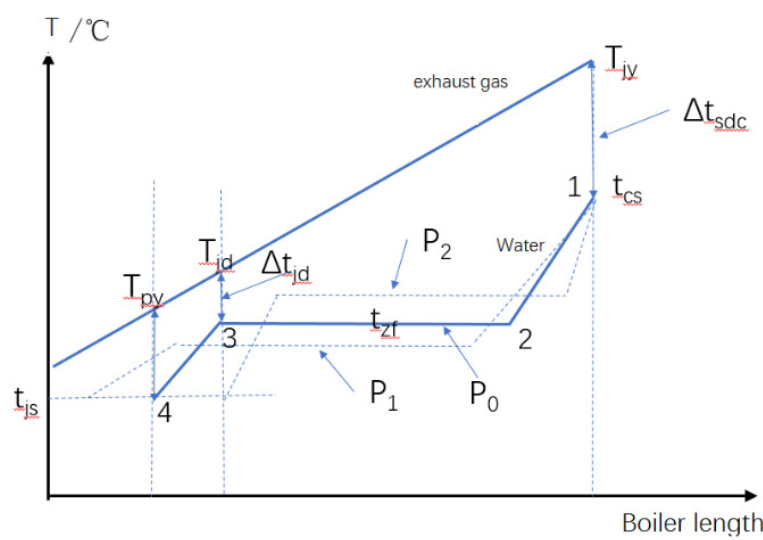

Fig.2. Thermodynamic calculation diagram of waste heat boiler system

Node temperature difference $\Delta t_{\mathrm{jd}}$ is an important design data, which directly affects the investment of waste heat boiler. According to engineering experience, it is generally taken as $15^{\circ} \mathrm{C}-18^{\circ} \mathrm{C}$. The upper end difference of 
boiler $\Delta t_{\mathrm{sdc}}$ is generally $25-30{ }^{\circ} \mathrm{C}$.

When superheated steam flows from the outlet of waste heat boiler to the inlet of steam turbine, there will be pressure drop and temperature drop due to pipe resistance and heat dissipation loss, but the value is small, which can be ignored in thermal system optimization. It is considered that the steam parameters at the outlet of steam turbine are the same as those at the outlet of boiler superheater.

Generally, the steam inlet point of the steam turbine is in the superheated steam area, but the exhaust steam of the steam turbine generally enters the two-phase area, that is, the wet steam area. It is impossible to use the temperature and pressure to determine the enthalpy value. The relative energy efficiency method is used in the design and calculation. Generally, the exhaust pressure of a steam turbine is known. It can be assumed that the inlet point of the steam turbine expands adiabatically to the exhaust isobaric line to obtain the isentropic enthalpy drop, and then calculate the actual enthalpy drop according to the relative internal efficiency of the steam turbine. The details are as follows (see Fig. 3)

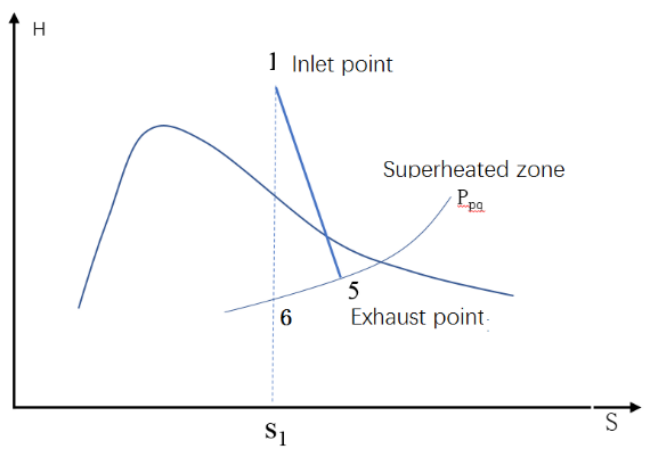

Fig.3 thermal calculation diagram of steam turbine system

(1) According to the inlet temperature $t_{\mathrm{cs}}$ and pressure $P_{0}$, the entropy value $S_{1}$ of steam turbine inlet point is calculated;

(2) The isentropic enthalpy $h_{6}$ is calculated according to the exhaust pressure $P_{\mathrm{pq}}$ of steam turbine and the entropy value $S_{1}$ of steam turbine inlet point;

(3) The actual enthalpy drop of steam in the steam turbine is calculated according to the relative internal efficiency $\eta_{\mathrm{s}}$ and isentropic enthalpy drop $\left(h_{1}-h_{6}\right)$;

(4) According to the superheated steam flow $m$, generator efficiency $\eta_{\mathrm{e}}$ and actual enthalpy drop, the generator output $W_{\mathrm{fd}}$ is calculated.

For the small steam turbine used for waste heat power generation, the relative internal efficiency is generally $81 \%$.

\subsection{Optimal design}

Generally, in the design of thermal system, the exhaust steam of steam turbine, the relative internal efficiency of steam turbine, the feed water temperature, the upper end difference of waste heat boiler and the node temperature difference are known, and the design pressure of waste heat boiler becomes the key design parameter. The optimal design is to select the appropriate boiler pressure to maximize the output power $W_{\mathrm{fd}}$ of the generator.

$$
\operatorname{Max}\left(W_{f d}\right)=\operatorname{Max}\left[m \times\left(h_{1}-h_{5}\right) \times \eta_{e}\right]_{p_{0 i}}
$$

In order to analyze the optimal boiler design pressure of waste heat power station, this paper combines the following cases to explain.

The waste heat power station is designed by using the flue gas resources of an industrial kiln. The flue gas parameters are shown in Table 1

Table 1 Parameters of flue gas waste heat

\begin{tabular}{|l|c|c|}
\hline \multicolumn{1}{|c|}{ project } & unit & parameters \\
\hline flue gas flow & $\mathrm{Nm}^{3} / \mathrm{h}$ & 88000 \\
\hline specific heat of flue gas & $\mathrm{kJ} /\left(\mathrm{Nm}^{3} \mathrm{C}\right)$ & 1.433 \\
\hline flue gas inlet temperature & ${ }^{\circ} \mathrm{C}$ & 376 \\
\hline $\begin{array}{l}\text { nodal temperature } \\
\text { difference }\end{array}$ & ${ }^{\circ} \mathrm{C}$ & 15 \\
\hline $\begin{array}{l}\text { upper end difference of } \\
\text { boiler }\end{array}$ & ${ }^{\circ} \mathrm{C}$ & 30 \\
\hline feed water temperature & ${ }^{\circ} \mathrm{C}$ & 39 \\
\hline turbine exhaust pressure & $\mathrm{kPa}$ & 7 \\
\hline $\mathrm{CO}_{2}$ content in flue gas & $\%$ & 24.94 \\
\hline $\mathrm{SO}_{2}$ content in flue gas & $\%$ & 0.00 \\
\hline $\mathrm{O}_{2}$ content in flue gas & $\%$ & 4.46 \\
\hline $\mathrm{N}_{2}$ content in flue gas & $\%$ & 66.00 \\
\hline $\mathrm{H}_{2} \mathrm{O}$ content in flue gas & $\%$ & 4.60 \\
\hline
\end{tabular}

It can be seen from the objective function (15) that the output power $W_{\mathrm{fd}}$ of the generator is related to the superheated steam flow $m$ and the enthalpy difference $\left(h_{1}-h_{5}\right)$ between the inlet and exhaust steam of the steam turbine.

(1) Relationship between boiler design pressure $P_{0}$ and feed water flow $m$

The flow rate of superheated steam and $\left(h_{1}-h_{3}\right)$ are related to the heat exchange $Q_{1}$ in the superheated section of boiler evaporation.

Firstly, the relationship between enthalpy difference $\left(h_{1}-h_{3}\right)$ and boiler design pressure $P_{0}$ is analyzed. It can be seen from Figure 4 that the higher the boiler design pressure is, the smaller the enthalpy difference (h1-h3) is. This is mainly because the higher the pressure is, the smaller the latent heat of water vaporization is.

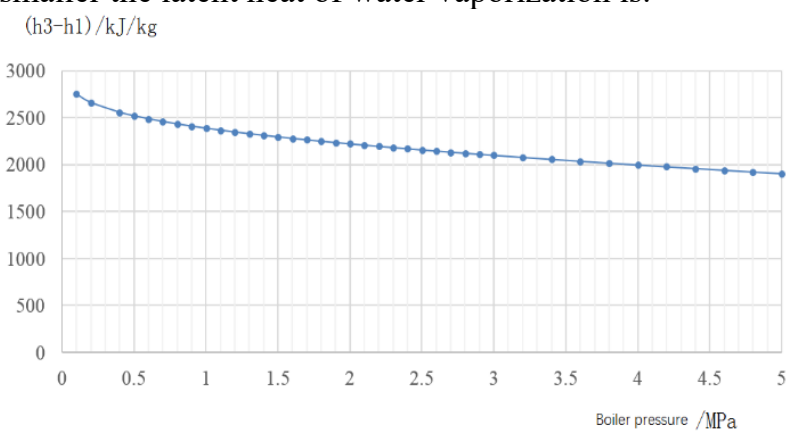

Fig 4 Relationship between $\left(h_{1}-h_{3}\right)$ and $P_{0}$

Then, the relationship between the heat exchange $Q_{1}$ and the design pressure $P_{0}$ is analyzed. The lower the boiler 
design pressure $P_{0}$ is, the lower the corresponding evaporation temperature $t_{\mathrm{zf}}$ is. Therefore, the lower the flue gas temperature $T_{j d}$ at the HRSG node is. Since the flue gas temperature at the boiler inlet remains unchanged, the larger the temperature difference $\left(T_{j y}-T_{j d}\right)$ is, the larger the corresponding heat exchange $Q_{1}$ is. Figure 5 shows the relationship between $Q_{1}$ and $P_{0}$

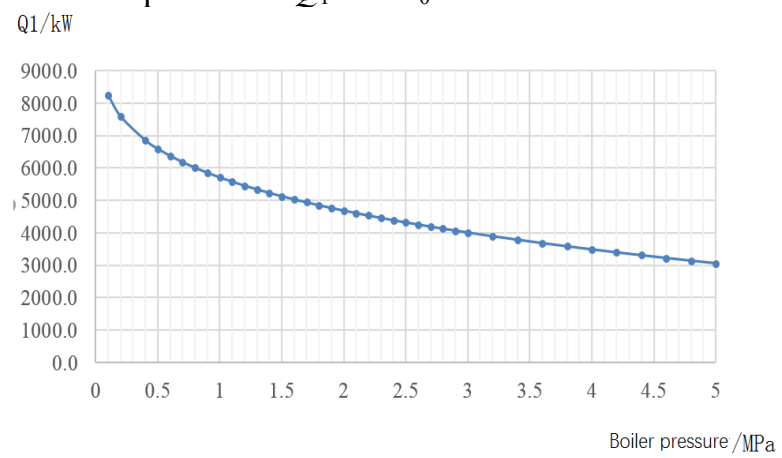

Fig 5 Relationship between $Q_{1}$ and $P_{0}$

Figure 6 shows the relationship between the superheated steam flow $m$ and the boiler design pressure $P_{0}$. It can be seen that the lower the boiler design pressure $P_{0}$, the greater the superheated steam flow $\mathrm{m}$. This is because although $\left(h_{1}-h_{3}\right)$ and $Q_{1}$ increase with the decrease of the boiler design pressure $P_{0}, Q_{1}$ increases faster than $\left(h_{1}-h_{3}\right)$.

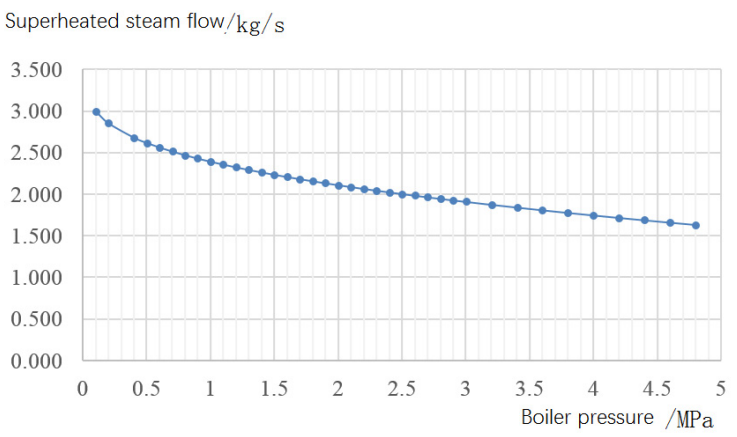

Fig 6 Relationship between $m$ and $P_{0}$

(2) Relationship between boiler design pressure $\boldsymbol{P}_{0}$ and $\left(h_{1}-h_{5}\right)$

When the difference between the inlet temperature of the boiler and the upper end of the boiler is determined, the inlet temperature of the steam turbine is determined. The higher the design pressure $P_{0}$ of the boiler is, the smaller the enthalpy $h_{1}$ of the steam turbine inlet is. On the premise of determining the exhaust pressure and relative energy efficiency of the steam turbine, the higher the design pressure $P_{0}$ of the boiler, the lower the exhaust enthalpy $h_{5}$ of the steam turbine.

It can be seen from Figure 7 that the steam turbine inlet enthalpy $\mathrm{H} 1$ and exhaust enthalpy H5 decrease with the increase of boiler design pressure $P_{0}$. Moreover, the decrease of steam turbine exhaust enthalpy $h_{5}$ with the increase of boiler design pressure $P_{0}$ is faster than that of steam turbine inlet enthalpy $h_{1}$. Therefore, the steam turbine enthalpy drop $\left(h_{1}-h_{5}\right)$ increases with the increase of boiler design pressure $P_{0}$, which is more intuitively reflected in Figure 8.

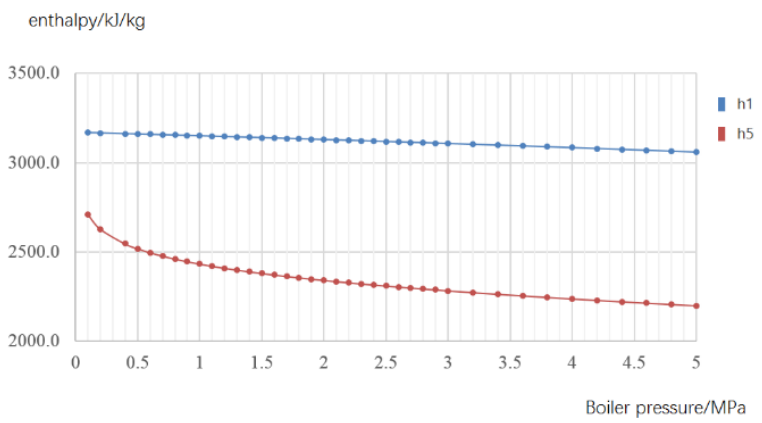

Fig 7 Relationship $h_{1}-P_{0}$ and $h_{5}-P_{0}$

When $P_{0}$ is less than $1 \mathrm{MPa}$, the enthalpy drop $\left(h_{1}-h_{5}\right)$ increases rapidly with the increase of design pressure $P_{0}$; when $P_{0}$ is greater than $1 \mathrm{MPa}$, the enthalpy drop $\left(h_{1}-h_{5}\right)$ increases slowly with the increase of design pressure $P_{0}$.

(h1-h5) $/ \mathrm{kJ} / \mathrm{kg}$

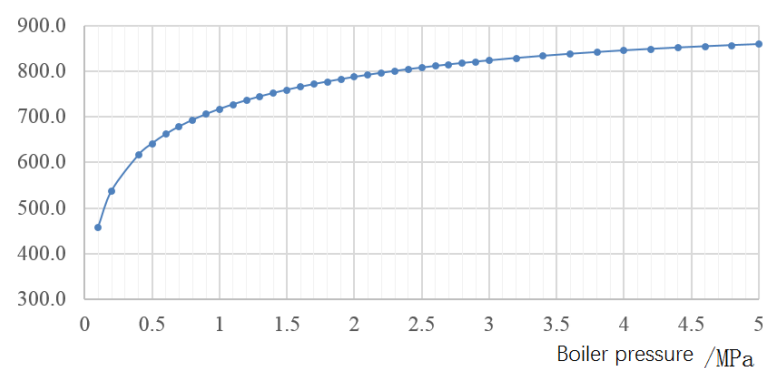

Fig 8 Relationship $\left(h_{1}-h_{1}\right)-P_{0}$

(3) Relationship between boiler design pressure $\boldsymbol{P}_{0}$ and generator output

The output power of the generator is related to the product of the superheated steam flow and the enthalpy difference of the steam turbine. The superheated steam flow $m$ decreases with the increase of the boiler design pressure, and the enthalpy difference of the steam turbine increases with the increase of the boiler design pressure.

Figure 9 provides the relationship between the boiler design pressure and the generator output. It can be seen that the generator output first increases and then decreases with the boiler design pressure. There is an obvious maximum value, and the boiler design pressure corresponding to this value is the best design pressure.

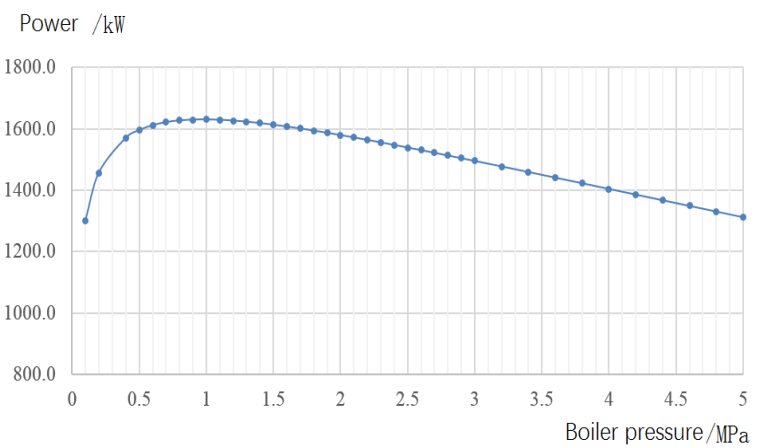

Fig 9 Relationship between generator output and boiler design pressure $P_{0}$ 
According to the basic data of case design, when different boiler design pressures are selected, the design parameters of thermal system for waste heat power generation are shown in Table 2.

Table 2 Design parameters under different boiler pressures

\begin{tabular}{|c|c|c|c|c|}
\hline pressure & $\begin{array}{l}\text { Steam } \\
\text { flow }\end{array}$ & $\begin{array}{l}\text { Exhaust gas } \\
\text { temperature }\end{array}$ & $\begin{array}{l}\text { enthalpy } \\
\text { drop }\end{array}$ & power \\
\hline $\mathrm{MPa}$ & $\mathrm{kg} / \mathrm{s}$ & ${ }^{\circ} \mathrm{C}$ & $\mathrm{kJ} / \mathrm{kg}$ & $\mathrm{kW}$ \\
\hline 0.1 & 2.996 & 90.7 & 457.0 & 1301.0 \\
\hline 0.2 & 2.853 & 104.6 & 537.6 & 1456.9 \\
\hline 0.4 & 2.680 & 121.5 & 616.5 & 1569.7 \\
\hline 0.5 & 2.617 & 127.7 & 641.5 & 1594.9 \\
\hline 0.6 & 2.563 & 133.1 & 661.8 & 1611.0 \\
\hline 0.7 & 2.514 & 137.9 & 678.7 & 1620.9 \\
\hline 0.8 & 2.470 & 142.2 & 693.3 & 1626.7 \\
\hline 0.9 & 2.429 & 146.2 & 706.0 & 1629.5 \\
\hline 1.0 & 2.392 & 149.9 & 717.3 & 1629.9 \\
\hline 1.1 & 2.357 & 153.4 & 727.3 & 1628.7 \\
\hline 1.2 & 2.324 & 156.7 & 736.5 & 1626.2 \\
\hline 1.3 & 2.293 & 159.8 & 744.8 & 1622.5 \\
\hline 1.4 & 2.264 & 162.7 & 752.4 & 1617.9 \\
\hline 1.5 & 2.235 & 165.6 & 759.4 & 1612.6 \\
\hline 2.0 & 2.110 & 178.1 & 787.6 & 1579.0 \\
\hline 2.5 & 2.004 & 188.8 & 808.2 & 1538.6 \\
\hline 3.0 & 1.910 & 198.3 & 823.9 & 1495.1 \\
\hline 4.0 & 1.748 & 214.8 & 845.8 & 1404.3 \\
\hline 5.0 & 1.607 & 229.1 & 859.6 & 1312.4 \\
\hline & & & & \\
\hline
\end{tabular}

According to the basic data of case design, through optimization calculation, the optimal design pressure of HRSG should be $1.05 \mathrm{Mpa}$, and the output of generator is $1630 \mathrm{kw}$. The design parameters of thermal system are shown in Table 3 and Table 4.

Table 3 Design parameters of water side

\begin{tabular}{|l|c|c|c|}
\hline State point & Temperatur & pressure & enthalpy \\
\hline unit & ${ }^{\circ} \mathrm{C}$ & $\mathrm{MPa}$ & $\mathrm{kJ} / \mathrm{kg}$ \\
\hline Water supply 4 & 39 & 1.05 & 164.24 \\
\hline Evaporator inlet 3 & 179.9 & 1.05 & 762.68 \\
\hline Evaporator outlet 2 & 179.9 & 1.05 & 2777.12 \\
\hline Boiler outlet 1 & 346 & 1.05 & 3149.67 \\
\hline Turbine exhaust 5 & 39 & 0.007 & 2432.39 \\
\hline $\begin{array}{l}\text { Isentropic enthalpy } \\
\text { drop point 6 }\end{array}$ & 39 & 0.007 & 2264.14 \\
\hline
\end{tabular}

Table 4 Other design parameters

\begin{tabular}{|l|c|l|c|}
\hline \multicolumn{1}{|c|}{ project } & value & \multicolumn{1}{c|}{ project } & value \\
\hline $\begin{array}{l}\text { Boiler node flue } \\
\text { gas temperature }\end{array}$ & $194.9^{\circ} \mathrm{C}$ & $\begin{array}{l}\text { Feed water } \\
\text { flow }\end{array}$ & $2.392 \mathrm{~kg} / \mathrm{s}$ \\
\hline $\begin{array}{l}\text { Exhaust gas } \\
\text { temperature }\end{array}$ & $149.9^{\circ} \mathrm{C}$ & $\begin{array}{l}\text { Generator } \\
\text { output }\end{array}$ & $1630 \mathrm{~kW}$ \\
\hline
\end{tabular}

\section{Conclusion}

When the flue gas parameters are fixed, the design pressure of the waste heat boiler is the key design parameter of the whole thermal system of waste heat power generation. There is an optimal design pressure of the boiler to maximize the power generation of the waste heat power station. The optimal boiler design pressure is related to flue gas temperature, upper end temperature difference and node temperature difference of waste heat boiler.

\section{References}

1. Z Chen, China Steel Focus, 11, 87-88.( 2019).

2. JL Gao, Energy Conservation \& Environmental Protection, 09,74-75. (2015)

3. S Dong, Electric Power Equipment Management, 02,93-96,(2020).

4. YM Liu, Research \& Application of Building Materials,01,29-30, (2020)

5. XX Chen, TJ Zhu, Energy and Environment, 06,5152.(2019).

6. JX Kang, Ceramics, 02,46-49,( 2019) 